\title{
How to Measure Personal Brand of a Business CEO
}

\author{
Hai Ming Chen, Hsin Mei Chung \\ Department of Management Sciences, Tamkang University, Taiwan \\ Email: haiming@mail.tku.edu.tw, mchung4525@gmail.com
}

How to cite this paper: Chen, H.M. and Chung, H.M. (2016) How to Measure Personal Brand of a Business CEO. Journal or Human Resource and Sustainability Studies, 4, 305-324

http://dx.doi.org/10.4236/jhrss.2016.44030

Received: November 4, 2016

Accepted: December 18, 2016

Published: December 21, 2016

Copyright $\odot 2016$ by authors and Scientific Research Publishing Inc. This work is licensed under the Creative Commons Attribution-NonCommercial International License (CC BY-NC 4.0). http://creativecommons.org/licenses/by-nc/4.0/

\begin{abstract}
A Chief Executive Officer (CEO) is the final decision maker of an enterprise and is the central figure influencing the culture of that enterprise. A CEO has a personal brand, which in collusion with a corporation's business brand casts a halo effect upon clients, customers, and employees, both present and potential. To date, most of the research on personal brands has been restricted to discussions over methods of building up personal brands: there has been no definitive research towards the construction of an evaluative scale of business CEO personal brands. Our current research has developed just such a scale, using seven evaluative dimensions to measure the work standards, competency, charisma, personality, values, character, and leadership qualities of a CEO. This unique scale enables users to clearly distinguish the personal brand of a business CEO. Researchers such as Bennis and O'Toole (2000) have suggested that boards of directors need to find more effective means of selecting their CEOs [1]. We believe that our scale can and should assist boards of directors faced with the question of whether a CEO's personal brand meets the expectations of their enterprise.
\end{abstract}

\section{Keywords}

Business CEO’s Personal Brand, Measure Scale, Leadership, Competency

\section{Introduction}

Countless prior brand studies have focused on both the creation and impact of strong business brands; however, parallel research is heretofore lacking in the field of the "personal brand" of the CEO. This study aims to characterize and develop a measurement scale with respect to a CEO's personal brand, and specifically to the extent and scope of the impact which a CEO's personal brand may have upon the commercial success of an enterprise and its internal corporate health.

The position of Chief Executive Officer (CEO) may be described as that of the "final manager" or the position of highest seniority within a corporation [2]. The CEO is the 
highest-ranking manager in a firm and is empowered by the company's stockholders. The board of directors authorizes the CEO to manage and make decisions for the enterprise. A CEO is the designated guardian of an enterprise [3] and their reputation is inextricably linked to their company's reputation [4].

It is the CEO who is generally held to be responsible for the successes and failures of a corporation, at the least during their tenure [5]; and by means of their legacy, the potential future successes and failures of the organization as well. The strategic policies enacted and executed by the CEO are aimed at the creation of greater customer value and, ideally, the generation of profit at a rate which increases or at least does not decrease [6]. A CEO may be critical for sustaining a corporate management style and role [7]. Furthermore, a CEO exerts strong influence upon an organization's decisionmaking processes and structures [8].

A number of researchers have highlighted the strong connections between CEO leadership, the performance of individual members of an organization [9], and organizational performance [10] [11]. Wang et al. (2011) have suggested that a CEO's behaviors are linked both directly and indirectly to firm performance [12]. One area in which high-profile organizations may retain and develop their competitive advantage is in the area of CEO reputation [13]. Furthermore, the personal and corporate values of a CEO bear a likely influence upon internal and external business culture [14]. A CEO's behavior influences employee performance [12] and business relationships.

In sum, CEOs are responsible for managing enterprises and representing corporations. Internally, the CEO behaves in the capacity not only of a manager but also of a role model, while externally the CEO acts on behalf of the corporation in full view of business partners, clients, and the public audience.

There is a long history of product and corporate brands to hand, and the literature associated with these types of brands is copious. We ask, what is of the "personal brand"?

A number of authors have presented the argument that a CEO's "personal brand" exerts a strong influence upon the course of an enterprise by (among other things) contributing at a fundamental level to the conveyance of a clear business brand image [15] [16], and attracting valuable employees to its business space [17].

What, then, are the parallels to be found, between the ways in which the more familiar concept of a business brand is cultivated and maneuvered, and the ways in which the "personal brand" of a CEO can and ought to be likewise handled?

Brands may apply to persons as well as commercial and corporate entities [18]. A personal brand definitively identifies an individual and allows others to become instantly familiar with that person's personality and values. These things are accomplished via branding techniques that are similar (or, in some cases, identical) to techniques now long applied to products and corporations at large [19].

In some regions of commerce, particularly those of product endorsement by famous sports and media figures, personal brands have become common and essential. Personal brands sustain and build up corporate brands through personal charisma.

A personal brand conveys a carefully pre-selected set of skills, ideas, and values 
which are to be associated with the personality and accomplishments of a public personage [19]. This manner of promotion has been proven to be powerfully effective. A commercial brand promoted in tandem with a personal brand may significantly increase company income and add value to a business [20]; while at the same time, a personal brand can increase personal income and add value to a person.

There is every reason to expect that a CEO's personal brand not only reflects upon his or her own self but may powerfully enhance the effectiveness of a commercial enterprise. The personal brand of a CEO is likely to be more effective at generating goodwill and brand equity than a corporate brand alone, if only because society trusts personalities more than it does businesses [21]. Audiences connect with a brand 100 times more quickly through a CEO's personal brand than through products or attachments to a business brand [21].

Altogether, a CEO's personal brand may prove to be an essential factor in a firm's performance, in a number of areas and at a number of levels. If that is in fact proven to be the reality, CEOs have upon them the onus to build and communicate their personal brands to expand both individual and corporate success [22].

There is, therefore, compelling justification for an examination of the ways in which a CEO's "personal brand" may wield influence in the corporate and commercial environment.

We assert that the "CEO personal brand", as a high-value intangible asset, should be actively incorporated into the lexicon and creative structure of the sphere of management. The personal brand of the CEO must be cultivated and promoted by any commercial organization for the purposes of competitive advantage.

\section{Literature Review}

One traditional definition of a brand reads: "the name, associated with one or more items in the product line, that is used to identify the source of character of the item(s)" [23].

According to Olins (2003) a brand is a symbolic embodiment of all the information connected to a company, product, or service [24]. The American Marketing Association (1960) identifies a brand as "a name, term, symbol, design, or any combination of these, intended to identify the goods or services of one seller or group of sellers and to differentiate them from those of competitors" [25].

Hankinson (2004) defined a brand as follow: (a) Brands are communicators that develop a product's differentiation by communicating a firm's vision of a brand and are used by an organization to communicate its positioning relative to its competitors. (b) Brands are perceptual entities that deliver sensation and feeling to consumers. (c) Brands are value enhancers, and brand equity refers to a brand's financial value. Marketers view brand equity as an indicator of future income, such as brand loyalty. (d) Brands are relationships of exchange that satisfy customer demand [26].

A brand is elsewhere defined as the method by which businesses inform customers of what to expect: a brand acts as a bridge between businesses and customers, and embo- 
dies the values espoused both by businesses and customers [27] [28].

A brand is able to add financial value to a business [20] and reduce the costs incurred by customers when searching for a product [29]. The value which an established brand imparts to an enterprise is sufficient to justify the costs of its development [30]: a well-developed brand is expected to improve evaluations, accessibility, and images related to a company [31]. What a brand, as a symbol, promises to customers is a crucial factor towards generation of customer faith and the establishment of loyalty from consumers [32].

From our perspective, following the above literature, a brand is a well-defined symbolic center whose dynamic spirit is capable of reflecting promises made to consumers of corporate, product, and service value. The outward purpose of a brand is to engender consumer trust. In action, a brand delivers a combination of sensations and feelings which communicate directly with consumers. A successful branding effort produces significant commercial benefits and adds value to a business.

Traditional brands embody the name and characteristics of a product or service and/or deliver an image and experience to consumers. Some researchers have expressed the view that an individual person may operate as a brand [33] [34] [35].

Aaker and Joachimsthaler (2000) described four types of brand that should be considered when organizing a brand framework: (a) brands that are products; (b) brands that are organizations; (c) brands that are people; and (d) brands that are symbols [36].

A successful branding effort ideally comprises the elements and dimensions of corporation, employer, employee, and product. To date, much research has focused primarily on the corporate and product aspects of branding, with little close regard for the role(s) of the human element. The field of personal branding is therefore ripe for more detailed examination and exploration.

Every person has a personal brand [28] to differentiate themselves from others. A personal brand is our willingness to adhere to the agreed standard performance level [28] and a strong personal brand is a mix of reputation, trust, attention, and execution [37]. A personal brand includes the professional and personal qualities [38] which distinguish a person from their peers, colleagues, and competitors, and which imply or promise something of value [39].

A personal brand reflects the existence of a particular type of personal understanding of the attitudes and feelings of others. Montoya identified a personal brand as "certain aspects of the public perception of a person's personality, skills, and values, that meaning is the value in the concept of audience" [19]. Therefore, a personal brand requires that one understand the unique combination of attributes and strengths, skills, values, and passions that guide one's career decisions [40].

McNally and Speak believed that a personal brand includes the internal and external characteristics of people-that is, people and others describe the interaction between each other and their overall impressions [41]. And they placed the idea of the brand in a personal context and defined a personal brand as "a perception or emotion, maintained by somebody other than you, that describes the total experience of having a rela- 
tionship with you" [18]. In addition, a personal brand is based on someone's reputation, public-image, legend, and character [42].

Based on this perspective, we argue that a personal brand is not related to creating an image, but to understanding the combination of attributes that is unique to a person. Therefore, a personal brand comprises the personality, strengths, skills, values, passions, lifestyle, public image, and character that differentiate a person and guide their decisions.

Follow Bendisch et al. (2013) research that CEO brands can be legitimately considered as brands [16]. A CEO is a vision constructor who provides motivation, carries out analyses, accomplishes his or her assigned duties, and determines the direction an organization shall follow [39]. He or she presumably is possessed of traditional management skills, and is capable of coordinating behaviors within an appropriate and consistent model; and he/she is able to bring in, establish, and settle vision and innovation unto and within the organization [43]. A CEO is the leader and lead manager of a firm, who guides this functional operation [44].

Roffer (2001) argued that a personal brand can reflect the core values, passions, and competencies of a person [45] and that leadership branding can reveal the competency, standard, and style of a leader [46]. Hart and Quinn (1993) have suggested that a CEO should be a vision setter, motivator, analyzer, and taskmaster [47].

Atalay and Yucel (2013) describe the expectation for a CEO to use such leadership "weapons"-that is, vision, strategy, financial policy, market orientation, goods and services, and corporate culture-to make his or her organization stand out from its competitors and maintain a strong position [6]. Meanwhile, a CEO's personal brand reflects how people experience their relationships with the CEO [18]. A successful CEO branding enhances perceived brand value and creates value for organisations [16].

The foregoing aspects of personal branding are essential and indispensable leadership characteristics which form the greater part of a CEO's personal brand. Hence, we have defined a CEO's personal brand as representing a CEO's individualized personality traits, values, competency, and leadership ethics which effectively differentiate a CEO and guide their decisions, enabling them to influence others deliberately.

Due to the strong effects which CEOs have on organizations [3] [4] [10] [11] [12] [14] [16] [17] [21] [46] [48] [49], it is crucial to the vitality of a firm to possess and utilize an effective means of evaluating and thereby "measuring" a CEO's personal brand: these measurements will then guide the firm in their choice of a more effective CEO. This study constructs a clearly defined and scaled measurement of a business CEO's personal brand characteristics.

Measuring a CEO's personal brand dimensions was necessary to achieve this goal. Previous studies have examined the construction and features of personal brands [22] [28] [38] [50], and Bendishc et al. (2013) had summarized people brand that focus in the constructs of image and reputation, but few have expressly and thoroughly described the dimensions and scale of CEO personal branding[16].

McNally and Speak (2001) have proposed three factors deemed necessary to main- 
tain a personal brand [18], but they did not sufficiently distinguish personal brands from other types of brands.

\section{Research Methods and Processes}

Based on the scale development phases of Spector (1991), we developed our scale in five phases [51]. The first phase requires the proposition of a preliminary definition, and thus this was constructed. The second phase requires a literature review; this, in tandem with expert interviews, was used to generate an initial pool of items to be considered for inclusion in the scale. In the third phase, the initial version of the scale was pilot-tested; subsequently, the architecture of the initial scale was completed, and the initial questionnaire was administered to participants in the study. In the fourth phase, participant responses were collected and principal components factor analyses were performed to simplify as well as sharpen the scale. The fifth phase included a second administration of the scale and subsequent examination of the reliability and validity of the components thus far assembled.

\subsection{Step 1: The Proposition of a Preliminary Definition Was Constructed}

Due to Peterson and Seligman (2003) believed that manager's character strengths be influenced by his or her performance [52] and CEO brands are influenced by their personality and their role as managers [16], all top level executives have their knowledge, experiences and leadership styles, in other words, they work have their own styles and them have a unique value by themselves [53]. Therefore, a preliminary definition of a "CEO personal brand" was constructed via the literature review cited in this paper. we defined the business CEO personal brand as a representation of a CEO's individual personality traits, values, competency, and leadership, especially should to focus on competency and personal dimensions of CEO images [54], especially insofar as these differentiate any given CEO from any other, and insofar as these guide the decisions of a CEO, enabling him or her to influence others in ways that may be considered significant enough not only to warrant but to enable the act of measurement.

\subsection{Step 2: A Literature Review and Interviews with Experts Were Used to Generate an Initial Pool of Items}

A CEO's personal brand comprises essential factors crucial to the act of distinguishing a given firm from other comparable firms. The personal brand of a CEO has a powerful effect on a corporation because it influences goodwill, brand equity, brand attachment [19], and business culture [14]. It is critical to determine which items should be considered to distinguish a business CEO's personal brand from other CEOs' personal brands. A thorough review of foregoing literature generates a composite understanding of the CEO personal brand as a multi-dimensional phenomenon, existing on both cognitive and tangible levels, which altogether represents a CEO's individual personality traits, and includes his or her values, competency, and leadership, overlaid upon a rea- 
listic and historical assessment of a CEO's ability to make critical decisions and influence others. Hence, according to the definitions of a personal brand as gathered and gleaned from the cited literature, the items to be included in the measurement scale were collected from these four domains: Personality Traits; Values; Competency; Leadership.

\subsubsection{Personality Traits}

Personality traits may be described as collusion between internal (cognitive and psychological) behaviors and modeled interpersonal behaviors [55]. Personality traits are looked to as prime factors in understanding an individual's ability to make decisions while also experiencing and responding to emotional states [56]. Guilford (1973) believed that personality traits are both unique and sustained, being exhibited through an individual's physiology, appearance, demands, interests, attitudes, idiosyncrasies, and hobbies [57].

Allport (1937) provides a somewhat differing assessment in his arguments that there are two fundamental levels within the foundation of a personality, the one being individual traits and the other "common" traits [34]: that is, an individual's genes compete with the stimuli of the external environment in order to produce the responses that we mark as personally distinctive, and therefore personality traits are reflected in individual behavior [58].

Certainly, many theories concerning the origins and character of personality traits have been published in the public literature; among these, we have found Costa and McCrae's "Big Five" (1989) to be the most credible and useful for the purposes of this study. This study, thereupon, follows Costa and McCrae's NEO-FFI (1989), a system of personality trait characterization and measurement focused upon the following itemized aspects of personal experience and expression: extraversion; emotional stability; openness to experience; agreeableness; and conscientiousness [59].

It is critical to note the following bias of our view: namely, that a manager's personality traits must be of little value in the absence of academic respectability and a vast, realistic, practical potential, for it is these two things (i.e., academic respectability and realistic practicality) which bear influence upon the performance of a firm.

We argue moreover that the $\mathrm{CEO}$, as the enterprise leader, is inherently incapable of accruing respect and exhibiting real functionality, barring possession of the following character features: humility [60]; self-confidence; moral and ideological appeal; high expectations for followers; confidence in subordinates; and thoughtful consideration [61]. We add to this the expectation that successful CEO personal brands will likely include a common pool of character features including passion, intelligence, and professional acumen.

Whereupon, the Personality Traits segment of this study contributes 41 items to the initial measurement scale, drawing directly from the personality traits of the Big Five [59]; clearly identified and crucial CEO personality traits; definitions of personal brands; and dimensions of general personality that are able to be treated as features of a brand [19] [41] [62]. 
3.2.2. Values

Personal branding value reflects on individual beliefs-that is, personal values. Values are basic beliefs or patterns of behavior which are not necessarily good or bad of them, but which profoundly affect an individual's attitudes and behaviors [63].

People with similar jobs or who belong to similar groups exhibit similar values [64], but values follow organizational culture, which is itself fundamentally affected by the values of the CEO [14]. Rokeach (1973) developed RVS (Rokeach Value Survey) scales, which propose 36 measurable items including "terminal values" and "instrumental values" [63]. Frederick and Weber (1990) proposed a Value Survey scale [64], which includes 10 such items as self-respect, happiness, freedom, family security, sense of accomplishment, ambition, capability, honesty, independence, and responsibility. Therefore, with particular reference to the research of Rokeach [63], and Frederick and Weber [64], we present a total of ten items as the initial measuring points in the category of Values.

\subsubsection{Competency}

Competency may be described as a combination of knowledge, character, motivation, social roles, and individual skills, which altogether and in concert have contributed to a history of excellent performance [65]. Miller and Droge (1986) have defined competency as intelligence and the ability to solve problems [8]. Spencer and Spencer (1993) developed the Competency Iceberg Model [66], which stipulates that motives, traits, and self-concept are located in the "hidden" part of the performer, while skills and knowledge are located in the visible part (i.e., as in the seen and unseen portions of an iceberg) [67]. Individual work competency involves knowledge, skills, and attitude [68] [69]. The competency of the character of an employee is exhibited over the process of project completion [70] and via a dynamic learning process [71]. Moreover, values, attitude, and motivations emerge during specific types and instances of situational interactions. Cheetham and Chivers (1996) collated and conjoined certain US and UK scholars' arguments that competency includes "knowledge/cognitive competence; functional competence; personal/behavioral competence; values/ethical competence" [72]. Chang (2003) argued that excellent competence demonstrated at higher levels of academic administration requires concurrent application of strategy, execution, attention, innovation, leadership, education, marketing, and technology [73].

Chisholm and Ely (1976) have suggested that problem solving, teamwork, conformity with regulations and control processes, and time management skills form the fundamental basis of the competence of the individual [68]. The competency of a successful leader will invariably include a vision set, communication skills, drive, ambition, interpersonal skills, team-orientated thinking, integrity, commitment, motivation, and ethics [74].

This study draws from the work of prior researchers to present 27 items as the initial measure points in the category of Competency [68] [69] [73].

\subsubsection{Leadership}

In a leadership study, Stogdill (1974) summarized the traits and skills that are critical to 
leaders by using "great man" theory and "trait" theory [75]. Relevant leadership traits include being adaptable, being alert to social environments, being ambitious, achievement-oriented, assertive, cooperative, decisive, dependable, dominant (expressing a desire to influence others), energetic (having a high activity level), persistent, self-confident, tolerant of stress, and willing to assume responsibility. Leaders need many skills, such as intelligence, conceptual skills, creativity, diplomacy, tact, eloquence, knowledge of group tasks, organization skills (administrative ability), skills of persuasion, and social skills.

McShane and Von Glinow (2000) synthesized seven items of competency and utility in leadership: drive, motivation, faithfulness, confidence, intelligence, business knowledge, and emotional intelligence [76]. Brownell and Goldsmith (2006) express that leadership competency includes "common" competencies and "distinctive" competencies, which respectively require developed professional knowledge, and developed personality traits and skills [77]. Collins (2001) has proposed that a leader must demonstrate humility and discernible personal ability in the areas of organizational, management, and motivational skills [60].

House et al. (1991) argued that self-confidence, moral and ideological appeal, high expectations of followers, confidence in subordinates, and consideration are basic characteristics of leaders [61]. House and Howell (1992) developed their "charisma" leadership theory, which proposes that a charismatic leader exhibits five traits: (a) strategic vision and articulation; (b) personal risk; (c) sensitivity to the environment; (d) sensitivity to member needs; and (e) unconventional behavior [78]. Atalay and Yucel (2013) describe CEO leadership "weapons" such as vision, strategy, financial policy, market orientation, good and services, and corporate culture to differentiate a firm from its competitors and maintain a strong market position [6].

For the purposes of this study, we have drawn primarily from House et al. [61], and Collins [60], to present 24 items as the initial measure points in the category of Leadership.

\section{SUMMARY: THE MEASUREMENT SCALE INITIAL ITEMS}

Following a review of extant literature, and of foregoing definitions of personal branding, in the regions of Personality Traits; Values; Competency and Leadership research, 102 scale items relevant to a business CEO personal brand were created for our measurement scale. Drawing from multiple areas of research, we developed an initial list of 102 items to be included in the CEO personal brand measurement scale.

Ten business experts with considerable field experience in management were invited to sort the 102 items. The discussion technique of Delphi method was used. The business experts had completed organizational behavior and marketing courses before and were familiar with known brand and leadership literature. We asked the business experts to review each of the items, to isolate the most relevant items, and to remove unessential items.

Twenty-two items were removed and we used the remaining 80 personal brand items for further refinement. To acquire greater validity and reliability in our study, we inter- 
viewed seven experts (four professors and three industry CEOs), who drew from their experience to identify the items that were most relevant to a business CEO's personal brand. The four professors were a university president, two directors of business management departments, and a professor from the business management department of a technology university. The three industry CEOs were a head of a private bank, a consultant in the travel industry, and the vice president of a well-known manufacturing conglomerate. The experts approved 70 items for use in the study.

\subsection{Step 3: The First Initial Version Was Pilot Tested; An Initial Scale Was Designed and the First Initial Questionnaire Was Administered}

In order to avoid ambiguous and confusing items, a pilot test of 70 items was administered to 40 students in departments of Business Management at several universities and institutes of technology. Based upon their feedback, we revised the words and phrasing of the items to facilitate clearer communication. We then completed the architecture of the initial measure scale.

The questionnaire began with a brief operational definition of a personal brand. Once the concept had been defined, a list of the names of six well-known business CEOs (include Steve Jobs-CEO of Apple, Bill Gates-Board of Microsoft, Morris Chang-Board of TSMC, Stan Shih-Board of Acer, Jerry Guo-CEO of Foxconn, or anyone who is the CEO familiar to you) was presented and the participants were asked to select only one of the six. The questionnaire then individually listed each of the 70 items as statements to be taken as potential descriptors of the CEO which they had selected, and the participants were asked to respondents evaluated features of the CEO to state to what degree each of the personal brand item statements fit with their knowledge and impressions of that CEO.

\subsection{Step 4: The Responses Were Collected and a Principal Components Factor Analysis Was Performed to Simplify the Scale}

The initial questionnaire included 70 items. Following Gorsuch (1983) (who stipulated that researchers should collect five times the number of questionnaires as the number of items on the questionnaire) [79], we required a minimum of 350 questionnaires to be completed. Whereupon, the questionnaire was provided to 90 students who study the program of Executive Master of Business Administration (EMBA) and Business Management department of technology university that included 3 universities at north area. We utilized what is known as the "snowball method" to ensure that the minimum quantity of questionnaires was achieved: once a student had completed a questionnaire, he or she was made to recommended five associates of similar academic stature who were capable of completing the questionnaire. Finial, 540 questionnaires were distributed and collected 405 questionnaires (an $81 \%$ response ratio). Of these questionnaires, 393 were completed (a 78.6\% effective recovery ratio).

Spector (1991) suggested that it is helpful at this stage of scale construction if the respondents to a study are as representative as possible of the ultimate audience population for which the study is intended [51]. We therefore made such use of the denizens 
of EMBA and Business Management programs, as these samples are precisely representative of the ultimate audience.

Each personal brand item statement was measured on a Likert scale: that is, the participants were asked to indicate on a five-point scale the extent to which the itemized statements described the behaviors of the selected business CEO. The scale ranged from one to five, wherein (1) indicates that the personal brand trait completely mismatches the traits of the business CEO; (2) indicates that the personal brand mismatches most of the CEO's traits; (3) indicates that the personal brand trait matches the traits of the business CEO to an average degree; (4) indicates that the personal brand trait matches the traits of the business CEO to a greater than average degree; and (5) indicates that the personal brand trait completely matches the traits of the business CEO.

We distributed 540 questionnaires and collected 405 questionnaires (an 81\% response ratio). Of these questionnaires, 393 were completed (a 78.6\% effective recovery ratio). Data were analyzed using Explore Factory Analysis (EFA), which was performed using principal component factor analysis with an Equamax rotation. To confirm that the data were suitable for factor analysis, a Kaiser-Meyer-Olkin (KMO) test and Bartlett test were used to check and support EFA (KMO test value of 0.967). An item was considered to load significantly on a factor if it exhibited a primary loading of 0.45 or more. Factor item analysis yielded seven factors, which accounted for more than $64.3 \%$ of the total variance. We used a Kaiser Criterion test (eigenvalues over 1) to identify seven factors. The seven factors included factors that contained 53 items that were clearly grouped according to a logical concept.

The seven factors were named based on the attributes of the survey questions and were used to create the following dimension names of the measurement scale.

1) Standards: Factor one account for $44.3 \%$ of the original variance and $30.9 \%$ of the explained variance. The factor reflects the quality of various types of standards which includes nine question items: process focus, financial focus, rule orientation, experience, strategy, planning, dedication, efficiency, and professionalism.

All question items above describe a business CEO's working standards, and therefore the dimension was named Standards.

2) Competency: Factor two accounts for $8.7 \%$ of the original variance and $6.1 \%$ of the explained variance. The factor reflects the quality of various types of competency which includes eight question items: toughness, creativity, consistency, tenacity, organizational skills, emotional intelligence, resoluteness, and thoughtfulness.

All question items above describe a business CEO's competency, therefore the dimension was named Competency.

3) Charisma: Factor three accounts for $3.3 \%$ of the original variance and $2.3 \%$ of the explained variance. The factor reflects the quality of various types of charisma which includes seven question items: ambition, charisma, leading ability, sense of environment, self-confidence, strategic vision, and mediation skills.

All question items above describe a business CEO's charisma, therefore the dimension was named Charisma. 
4) Style: Factor four accounts for $2.6 \%$ of the original variance and $1.8 \%$ of the explained variance. The factor reflects the quality of various types of style which includes seven question items: outgoing, curiosity, human spirit, energy, daring, independence, and imagination.

All question items above describe a business CEO's style, therefore the dimension was named Style.

5) Value: Factor five accounts for $2.0 \%$ of the original variance and $1.4 \%$ of the explained variance. The factor reflects the quality of various types of value which includes eight question items: family security, happiness, friendliness, politeness, simplicity, humility and modesty, stability, and amiability.

All question items above describe a business CEO's value, therefore the dimension was named Value.

6) Character: Factor six accounts for $1.8 \%$ of the original variance and $1.2 \%$ of the explained variance. The factor reflects the quality of various types of character which includes six question items: reliability, commitment, honesty, obliging, justness, and responsibility

All question items above describe a business CEO's character, therefore the dimension was named Character.

7) Leadership: Factor seven accounts for $1.6 \%$ of the original variance and $1.2 \%$ of the explained variance. The factor reflects the quality of various types of leadership which includes eight question items: cooperativeness, demonstrated trust toward subordinates, respect for others, willingness to accept suggestions, forgiveness, communication, expectations of followers, and leadership skills.

All question items above describe a business CEO's leadership, therefore the dimension was named Leadership.

\subsection{Step 5: The Second Administration of the Scale and Examination of Its Reliability and Validity}

The revised questionnaire included 53 items from 7 dimensions. This questionnaire was distributed to another sample of 300 EMBA students, as well as professionally employed students who were concurrently enrolled at a technology university. The students were known to be familiar with organizational behavior theory, and to have had work experience.

We calculated Cronbach's Alpha to estimate the internal consistency reliability. The results of the first internal consistency reliability test (Cronbach's Alpha) for the subscales of step 4 were as follows: 0.931 for Standards, 0.932 for Competency, 0.921 for Charisma, 0.883 for Style, 0.894 for Values, 0.874 for Character, and 0.896 for Leadership. The second test confirmed the reliability of the subscales of step 5 with the following results: 0.930 for Standards, 0.934 for Competency, 0.922 for Charisma, 0.883 for Style, 0.880 for Values, 0.865 for Character, and 0.956 for Leadership.

These results indicated that the CEO's personal brand measurement scale was reliable. Table 1 shows the estimated coefficients. 
To confirm and gauge the validity of the structure and substance of the measurement scale, respondents to the questionnaire were presented with each question two separate times. In accordance with our own predictions, correlations between specific subscales and the construct in general were found to be high. The results shown in Table 2 proved

Table 1. Internal consistency reliability.

\begin{tabular}{ccc}
\hline \multirow{2}{*}{ Scale dimensions } & \multicolumn{2}{c}{ Cronbach' $\boldsymbol{\alpha}$} \\
\cline { 2 - 3 } & Initial questionnaire application & Second questionnaire application \\
\hline Standard & 0.931 & 0.930 \\
Competency & 0.932 & 0.934 \\
Charisma & 0.921 & 0.922 \\
Style & 0.883 & 0.883 \\
Values & 0.894 & 0.880 \\
Character & 0.874 & 0.865 \\
Leadership & 0.896 & 0.956 \\
\hline
\end{tabular}

Table 2. Basic descriptive parameters of the questionnaire in its initial and second application.

\begin{tabular}{|c|c|c|}
\hline Descriptive parameters & Initial application & Second application \\
\hline \multicolumn{3}{|l|}{ Mean (standard deviation) } \\
\hline Standard & $21.17(3.57)$ & $21.30(3.10)$ \\
\hline Competency & $21.49(3.54)$ & $21.61(3.11)$ \\
\hline Charisma & $22.09(3.46)$ & $22.28(2.95)$ \\
\hline Style & $20.49(3.44)$ & $20.55(3.03)$ \\
\hline Values & $17.79(3.87)$ & $17.82(3.61)$ \\
\hline Character & $19.34(3.68)$ & $19.41(3.49)$ \\
\hline Leadership & $18.96(3.60)$ & $19.04(3.31)$ \\
\hline \multicolumn{3}{|l|}{ Range } \\
\hline Standard & $9-45$ & $14-45$ \\
\hline Competency & $8-40$ & $10-40$ \\
\hline Charisma & $7-35$ & $7-35$ \\
\hline Style & $7-34$ & $9-34$ \\
\hline Values & $12-33$ & $12-33$ \\
\hline Character & $7-29$ & $7-29$ \\
\hline Leadership & $9-35$ & $13-35$ \\
\hline \multicolumn{3}{|l|}{ Relative range } \\
\hline Standard & 0.8 & 0.69 \\
\hline Competency & 0.8 & 0.75 \\
\hline Charisma & 0.8 & 0.8 \\
\hline Style & 0.79 & 0.74 \\
\hline Values & 0.64 & 0.64 \\
\hline Character & 0.76 & 0.76 \\
\hline Leadership & 0.74 & 0.63 \\
\hline
\end{tabular}


the first to be corrected by the second.

\section{Research Results}

Via this study, we have developed a business CEO personal brand measurement scale. The scale includes seven dimensions:

1) Standards - this dimension included nine items used to measure a business CEO's working standards. This dimension includes the terms process focus, financial focus, rule orientation, experience, strategy, planning, dedication, efficiency, and professionalism.

2) Competency-this dimension includes eight terms: toughness, creativity, consistency, tenacity, organizational skills, emotional intelligence, resoluteness, and thoughtfulness.

3) Charisma-this dimension includes seven items needed in order to measure a business CEO's personal charisma, including ambition, charisma, leading ability, sense of environment, self-confidence, strategic vision, and mediation skills. Each of these items addresses a separate aspect of a CEO's image and is applicable insofar as respondent knows who he or she is.

4) Style-this dimension includes seven facets of a business CEO's individual personality. This dimension contains the terms outgoing, curiosity, human spirit, energy, daring, independence, and imagination.

5) Values-this dimension includes eight items to measure a business CEO's work values. The terms for this dimension are family security, happiness, friendliness, politeness, simplicity, humility and modesty, stability, and amiability.

6) Character-this dimension includes six terms to measure a business CEO's individual character, including reliability, commitment, honesty, obliging, justness, and responsibility.

7) Leadership - this dimension includes eight items used to measure a business CEO's leadership skills, including cooperativeness, demonstrated trust toward subordinates, respect for others, willingness to accept suggestions, forgiveness, communication, expectations of followers, and leadership skills.

The measure items of business CEO personal brands are designed as shown in Table 3.

\section{Discussion and Conclusion}

Traditional brand research has focused on building up product or business brands; however, studies of the qualities, dimensions, and parameters of a business CEO personal brand have heretofore been lacking. Notwithstanding, previous research has provided fertile ground for the development of the principles of building a personal brand [21] [28] [38]. McNally and Speak (2002) formulated three approaches aimed at improving individual abilities [28], but they neglected to address the concepts of personal brand dimensions and a measurement scale.

In practice, a personal brand reflects how others regard that person, versus self-regard. 
Table 3. The dimensions and items.

\begin{tabular}{|c|c|}
\hline Dimension & items \\
\hline $\begin{array}{l}\text { Standard } \\
(9 \text { items })\end{array}$ & $\begin{array}{l}\text { Process focus, financial focus, rule orientation, experience, strategy, planning, dedication, } \\
\text { efficiency, professional }\end{array}$ \\
\hline $\begin{array}{l}\text { Competency } \\
\text { (8 items) }\end{array}$ & $\begin{array}{l}\text { Toughness, creativity, consistency, hold key point, organize skills, emotional intelligence, } \\
\text { resolution, thoughtfulness }\end{array}$ \\
\hline $\begin{array}{l}\text { Charisma } \\
\text { (7 items) }\end{array}$ & $\begin{array}{l}\text { Ambition, charisma, leading ability, sense of environment, self-confidence, strategic } \\
\text { vision, meditation skills }\end{array}$ \\
\hline $\begin{array}{c}\text { Style } \\
\text { (7 items) }\end{array}$ & Outgoing, curiosity, human spirit s, energy, daring, independence, imaginativeness \\
\hline $\begin{array}{l}\text { Values } \\
\text { (8 items) }\end{array}$ & $\begin{array}{l}\text { Family security, happiness, friendliness, politeness, simplicity, humility and modesty, } \\
\text { stability, amiability }\end{array}$ \\
\hline $\begin{array}{l}\text { Character } \\
\text { (6 items) }\end{array}$ & Reliability, commitment, honesty, obliging, justness, and responsibility \\
\hline $\begin{array}{l}\text { Leadership } \\
\text { (8 items) }\end{array}$ & $\begin{array}{l}\text { Cooperativeness, trusting subordinates, respect to others, willingness to accept } \\
\text { suggestions, forgiveness, communication, expectations of followers, leadership skills }\end{array}$ \\
\hline
\end{tabular}

A CEO's personal brand reflects how people experience their relationships with the CEO. The personal brand of a business CEO, in particular, is built up upon stakeholder opinions. We have defined a CEO's personal brand as that which represents a CEO's individual personality, character, strengths, skills, values, passions, lifestyle, public image, and leadership traits, and we assert that this body of attribute differentiates the $\mathrm{CEO}$ and guides their decisions, enabling him or her to influence others to a greater or lesser degree.

This study gathered formative information from the literature of various sectors of research, including those pertaining to Personality Traits; Values; Competency and Leadership research, and from that gleaning there was an initial measurement pool of 102 items developed. We followed the scale development construction process described by Spector [51] to identify seven dimensions and 53 items usable to measure a business CEO's personal brand. The identification of the seven dimensions of measurement (standards, competency, charisma, style, values, character, and leadership) and analysis support our thesis that the personal brand is in fact a multidimensional construct.

A CEO plays a crucial role in the success and survival of an organization. He or she shapes the future of the organization in no small part by guiding various social and corporate perceptions which continually take place while the CEO is making life-anddeath decisions for the organization. Therefore, the measurement scale was created to identify the characteristics of a business CEO's personal brand and render it more perceptible and tangible. Our research suggests that the scale we have developed is in fact unique, especially insofar as it enables users to clearly distinguish the personal brand of a business CEO. We go further to state, with great confidence that the CEO measurement scale could prove to be a valuable tool of prognostication to boards of directors, 
both in the present and in the future, to assist in confirming whether or not a CEO meets the expectations of the enterprise.

The research described here represents the first effort to develop a scale to measure a business CEO's personal brand. Although we have developed and tested the scale within a business sphere, it has not otherwise been applied to other types of public venues and personas.

\section{References}

[1] Bennis, W. and O’Toole, J. (2000) Don't Hire the Wrong CEO. Harward Business Review, 78, 170-177.

[2] Ko, C.E. (2007) Who is CEO. Economic Daily News, 27 August.

[3] Alsop, R.J. (2004) The 18 Immutable Laws of Corporate Reputation: Creating, Protecting and Repairing Your Most Valuable Asset. Free Press, New York.

[4] Turk, J.V., Jin, Y., Stewart, S. and Hipple, J.R. (2012) Examining the Interplay of an Organization's Prior Reputation, CEO's Visibility, and Immediate Response to a Crisis. Public Relations Review, 38, 574-583. https://doi.org/10.1016/j.pubrev.2012.06.012

[5] Tekin, Y. (2007) A Modern Leadership Approach Visionary Leadership: A Research in Accommodation Facilities with 5 Stars Carrying on Business in Antalya. Akdeniz University, Institute of Social Sciences, Antalya.

[6] Atalay, A. and Yucel, A.S. (2013) “CEO” Applications in Modern Sports Management. International Journal of Academic Research Part B, 5, 19-25.

[7] Liberatore, M.J. and Titus, G.J. (1990) A Comparison of Strategic Planning Processes in US Industrial Corporations. In: Dean, B.V. and Cassidy, J.C., Eds., Strategic Management: Methods and Studies, Elsevier Publishers, North Holland.

[8] Miller, D. and Droge, C. (1986) Psychological and traditional Determinants of Structure. Administrative Science Quarterly, 31, 539-560. https://doi.org/10.2307/2392963

[9] House, R. (1999) Weber and Noe-Charismatic Leadership Paradigm: A Response to Beyer. Leadership Quarterly, 10, 563-565. https://doi.org/10.1016/S1048-9843(99)00032-6

[10] Reinganum, M.R. (1985) The Effect of Executive Succession on Stockholder Wealth. Administrative Science Quarterly, 30, 46-60. https://doi.org/10.2307/2392811

[11] Thomas, A.B. (1988) Does Leadership Make a Difference to Organizational Performance? Administrative Science Quarterly, 33, 388-400. https://doi.org/10.2307/2392715

[12] Wang, H., Tsui, A.S. and Xin, K.R. (2011) CEO Leadership Behaviors, Organizational Performance, and Employees' Attitudes. The Leadership Quarterly, 22, 92-105. https://doi.org/10.1016/j.leaqua.2010.12.009

[13] Ranft, A.L., Zinko, R., Ferris, G.R. and Buckley, M.R. (2006) Marketing the Image of Management: The Costs and Benefits of CEO Reputation. Organizational Dynamics, 35, 279290. https://doi.org/10.1016/j.orgdyn.2006.05.003

[14] Schein, E.H. (1992) Organization Culture and Leadership. 2nd Edition, Jossey-Bass, San Francisco.

[15] McCracken, G. (1989) Who Is the Celebrity Endorser? Cultural Foundations of the Endorsement Process. Journal of Consumer Research, 16, 310-321. https://doi.org/10.1086/209217

[16] Bendisch, F., Larsen, G. and Trueman, M. (2013) Fame and Fortune: A Conceptual Model of CEO Brands. European Journal of Marketing, 47, 596-614. 
https://doi.org/10.1108/03090561311297472

[17] Cable, D.M. and Turban, D.B. (2001) Establishing the Dimensions, Sources and Value of Job Seekers' Employer Knowledge during Recruitment. In: Cable, D.M. and Turban, D.B., Eds., Research Personal and Human Resources Management, Emerald Group Publishing Limited, Bingley, 115-163. https://doi.org/10.1016/s0742-7301(01)20002-4

[18] McNally, D. and Speak, K.D. (2001) Be Your Own Brand: A Breakthrough Formula for Standing Out from the Crowd. Berrett-Koehler, San Francisco.

[19] Montoya, P. (2002) The Personal Branding Phenomenon. Personal Branding Press, New York.

[20] Simon, C.J. and Sullivan, M.J. (1993) The Measurement and Determinants of Brand Equity: A Financial Approach. Marketing Science, 12, 28-52. https://doi.org/10.1287/mksc.12.1.28

[21] Montoya, P. (2002) The Brand Called You: The Ultimate Brand Building and Business Development. Personal Branding, Nashville.

[22] Arruda, W. (2004) Brand Connection. Executive Excellence, 21, 4.

[23] Kotler, P. (2000) Marketing Management. The Millennium Edition, Prentice Hall, Upper Saddle River.

[24] Olins, W. (2003) On Brand. Thames \& Hudson, London.

[25] American Marketing Association (1960) Marketing Definitions: A Glossary of Marketing Terms. American Marketing Association, Chicago.

[26] Hankinson, G. (2004) Relational Network Brands: Towards a Conceptual Model of Place Brands. Journal of Vacation Marketing, 10, 109-121. https://doi.org/10.1177/135676670401000202

[27] Kotler, P. (1998) A Generic Concept of Marketing. Marketing Management, 7, 48-54.

[28] McNally, D. and Speak, K.D. (2002) Be Your Own Brand. American Salesman, 47, 29-30.

[29] Keller, K.L. (1993) Conceptualizing, Measuring and Managing Customer-Based Brand Equity. Journal of Marketing, 57, 1-22. https://doi.org/10.2307/1252054

[30] Faquhar, P.H. (1989) Managing Brand Equity. Marketing Research, 1, 24-33.

[31] Aaker, D.A. (1991) Managing Brand Value: Capitalizing on the Value of a Brand Name. Free Press, New York.

[32] Kotler, P. and Keller, K. (2006) Marketing Management. Pearson Prentice Hall, Upper Saddle River.

[33] Hirschman, E.C. (1987) People as Products: Analysis of a Complex Marketing Exchange. Journal of Marketing, 51, 98-108. https://doi.org/10.2307/1251147

[34] Allport, G.W. (1937) Personality-A Psychological Interpretation. Henry Holt and Company, New York.

[35] Fournier, S. (2010) Taking Stock in Martha Stewart: A Cultural Critique of the Marketing Practice of Building Person-Brands. In: Campbell, M.C., Inman, J. and Pieters, R., Eds., NA-Advances in Consumer Research Volume 37, Association for Consumer Research, Duluth, 37-40.

[36] Aaker, D.A. and Joachimsthaler, F. (2000) Brand Leadership: Building Assets in the Information Society. Free Press, New York.

[37] Harris, L. and Rae, A. (2011) Building a Personal Brand through Social Networking. Journal of Business Strategy, 32, 14-21. https://doi.org/10.1108/02756661111165435

[38] Montoya, P. and Vandehey, T. (2008) The Brand Called You: Create a Personal Brand That Wins Attention and Grows Your Business. McGraw-Hill, New York. 
[39] Arruda, W. (2004) Brand Connection. Executive Excellence, 21, 4.

[40] Arruda, W. and Dixson, K. (2010) Career Distinction: Stand Out by Building Your Rand. John Wiley \& Sons, Inc., Hoboken.

[41] McCrae, R.R. and Costa, P.T. (1987) Validation of the Five-Factor Model of Personality across Instruments and Observers. Journal of Personality and Social Psychology, 52, 81-90. https://doi.org/10.1037/0022-3514.52.1.81

[42] D’Alessandro, D.F. (2004) Career Warfare: 10 Rules for Building a Successful Personal Brand and Fighting to Keep It. McGraw-Hill, New York.

[43] Hambrick, D.C. and Fukutomi, G.D.S. (1991) The Seasons of a CEO's Tenure. Academy of Management Review, 16, 719-742.

[44] Hamel, G. and Parahalad C.K. (1996) Winning the Future. Dicleli, U., Trans., Inkilap Bookshop, Istanbul.

[45] Roffer, R.F. (2001) Employment Relations Today: Helping Employees Retool Their Brand after a Layoff. John Willey \& Sons, San Francisco.

[46] Whang, H. (2002) CEO Leadership Attributes and Organizational Effectiveness: The Role of Situational Uncertainty and Organizational Culture. The Hong Kong University, Hong Kong.

[47] Hart, S.L. and Quinn, R.E. (1993) Roles Executives Play: CEOs, Behavioral Complexity, and Firm Performance. Human Relations, 46, 543-574. https://doi.org/10.1177/001872679304600501

[48] Smith, M. and White, M.C. (1987) Strategy, CEO Specialization, and Succession. Administrative Science Quarterly, 32, 263-280. https://doi.org/10.2307/2393129

[49] Naidoo, V. and Ukpere, W.I. (2012) Leadership as a Key Element in the Effective Alignment and Internal Branding in Organisations. African Journal of Business Management, 6, 9543-9548.

[50] Close, A.G., Moulard, J.G. and Monroe, K.B. (2011) Establishing Human Brands: Determinants of Placement Success for First Faculty Positions in Marketing. Journal of the Academy Marketing Science, 39, 922-941. https://doi.org/10.1007/s11747-010-0221-6

[51] Spector, P. (1991) Summated Rating Scale Construction: An Introduction. Sage Publications, Inc., London.

[52] Peterson, C. and Seligman, M.E.P. (2003) Character Strengths before and after September 11. Psychological Science, 14, 381-384. https://doi.org/10.1111/1467-9280.24482

[53] Bates, S. (2012) Discover Your CEO Brand: Secrets to Embracing and Maximizing Your Unique Value as a Leader. McGraw-Hill Education, New York.

[54] Park, D.J. and Berger, B.K. (2004) The Presentation of CEOs in the Press, 1990-2000: Increasing Salience, Positive Valence, and a Focus on Competency and Personal Dimensions of Image. Journal of Public Relations Research, 16, 93-125. https://doi.org/10.1207/s1532754xjprr1601 4

[55] Mackinnon, N.J. (1994) Symbolic Interaction as Affect Control. State University of New York Press, Albany.

[56] Perry, B.D. (1997) Incubated in Terror: Neurodevelopmental Factors in the "Cycle of Violence". In: Osofsky, J., Ed., Children in a Violent Society, Guilford Press, New York, 124-148

[57] Guilford, J.P. (1973) On Personality: In Readings in Personality. Holt, New York.

[58] Schultz, D.P. and Schultz, S.E. (2012) Theories of Personality. 10th Edition, Cengage 
Learning, Boston.

[59] Costa, P.T. and McCrae, R.R. (1989) The NEO-PI/NEO-FFI Manual Supplement. Psychological Assessment Resources, Odessa.

[60] Collins, J. (2001) Level 5 Leadership: The Triumph of Humility and Fierce Resolve. Harvard Business Review, 79, 67-76.

[61] House, R.J., Spangler, W.D. and Woycke, J. (1991) Personality and Charisma in the US Presidency: A Psychological Theory of Leader Effectiveness. Academy of Management Journal, 36, 364-396. https://doi.org/10.2307/2393201

[62] Aaker, J.L. (1997) Dimensions of Brand Personality. Journal of Marketing Research, 34, 347-356. https://doi.org/10.2307/3151897

[63] Rokeach, M. (1973) The Nature of Human Value. Free Press, New York.

[64] Frederick, W.C. and Weber, J. (1990) The Values of Corporate Managers and Their Critics: An Empirical Description and Normative Implication. In: Frederick, W.C. and Preston, E., Eds., Business Ethics: Research Issues and Empirical Studies, Emerald Group Publishing Limited, Bingley, 123-144.

[65] Boyatzis, R.E. (1982) The Competent Manager: A Model for Effective Performance. John Wiley \& Sons, Inc., Toronto.

[66] Spencer, L.M. and Spencer, S.M. (1993) Competence at Work: Models for Superior Performance. John Wiley \& Sons, New York.

[67] Chen, H.M. and Chang, W.Y. (2010) The Essence of the Competence Concept: Adopting an Organization's Sustained Competitive Advantage Viewpoint. Journal of Management \& Organization, 16, 677-699. https://doi.org/10.1017/S1833367200001802

[68] Chisholm, M.E. and Ely, D.P. (1976) Media Personnel in Education: A Competency Approach. Prentice-Hall, Englewood Cliffs.

[69] Parry, B.S. (1998) Just What Is a Competency? And Why Should You Care? Training, 35, 58-64.

[70] Haland, E. and Tjora, A. (2006) Between Asset and Process: Developing Competence by Implementing a Learning Management System. Human Relations, 59, 993-1016. https://doi.org/10.1177/0018726706067599

[71] Simpson, B. (2002) The Knowledge Needs of Innovating Organizations. Singapore Management Review, 24, 51-60.

[72] Cheetham, G. and Chivers, G. (1996) Towards a Holistic Model of Professional Competence. Journal of European Industrial Training, 20, 20-30.

https://doi.org/10.1108/03090599610119692

[73] Chang, M.H. (2003) The Crucial Competence of Excellent School President. Journal of Social Education, 114, 15-19.

[74] Tait, R. (1996) The Attributes of Leadership. Leadership and Organization Development Journal, 17, 27-31. https://doi.org/10.1108/01437739610785405

[75] Stogdill, R.M. (1974) Handbook of Leadership: A Survey of the Literature. Journal of Psychology, 25, 35-71. https://doi.org/10.1080/00223980.1948.9917362

[76] McShane, S.L. and von Glinow, M.A. (2000) Organizational Behavior. McGraw-Hill, Boston.

[77] Brownell, J. and Goldsmith, M. (2006) Commentary on Meeting the Competency Needs of Global Leaders: A Partnership Approach. Human Resource Management, 45, 309-336. https://doi.org/10.1002/hrm.20115 
[78] House, R.J. and Howell, J.M. (1992) Personality and Charismatic Leadership. The Leadership Quarterly, 3, 81-108. https://doi.org/10.1016/1048-9843(92)90028-E

[79] Gorsuch, R.L. (1983) Factor Analysis. Lawrence Erlbaum Associates, Hillsdale.

Submit or recommend next manuscript to SCIRP and we will provide best service for you:

Accepting pre-submission inquiries through Email, Facebook, LinkedIn, Twitter, etc.

A wide selection of journals (inclusive of 9 subjects, more than 200 journals)

Providing 24-hour high-quality service

User-friendly online submission system

Fair and swift peer-review system

Efficient typesetting and proofreading procedure

Display of the result of downloads and visits, as well as the number of cited articles

Maximum dissemination of your research work

Submit your manuscript at: http://papersubmission.scirp.org/

Or contact jhrss@scirp.org 